\title{
Use of the discourse analysis method to study current political practice (by the example of representation of the political leader image)
}

\author{
Nadezhda Frolova ${ }^{1}$, Anna Morozova $^{2,}$ a and Alexander Pushkov ${ }^{1}$ \\ ${ }^{1}$ Prioksky State University, Orel, Russia \\ ${ }^{2}$ Bryansk State Technical University, Bryansk, Russia
}

\begin{abstract}
The potentialities in the application of the discourse analysis method to study a political discourse as a current political practice are shown. The authors, using the Foucault methodology, offer a sociological definition for the political discourse. It is the authors' opinion that the approach mentioned allows investigating a political discourse as a practice for the formation of a certain reality, specific agents, institutions and organizations. A political discourse is a simulative dynamic model of political area where various subdiscourses interact, thus creating their own ideas of policy, symbols and images. Subdiscourses of political leaders become dominating. Inasmuch as a political discourse in a current political system is carried out with the aid of mass media, it could be considered as a media discourse of policy. The authors consider the representation as a basic mechanism for the formation of a political discourse, by the example of the representation of the image of V.V. Putin, the President of the Russian Federation. The representation of a political leader image in a political discourse has a number of peculiarities. It is carried out on the basis of certain principles with the aid of the system of political codes. Empiric investigations allowed making a conclusion that the main symbolic image for the Russian President is an image of a super-hero. It is the authors' opinion, the image of V.V. Putin as a leader super-hero is determined by the specificity of the Russian political culture within the limits of which a leader is a center of power establishing an authoritarian style of ruling. The authors show the process of the political legitimacy displacement from the institutional level to the personal one by means of mass media. A political leader gains a status of a subject establishing moral, social and value reference points for the whole of the society.
\end{abstract}

\section{Introduction}

In modern society the problem of political leadership is as relevant as ever, in which connection it is analyzed from both general and theoretical positions [7, 8, 11, 25], taking into account an applied specificity : territorial $[9$, $15,17,18,19,23,24,26,27]$, gender [13, 14, 21, 29] and so on. In the Russian society the leadership was always the most significant institution of social transformations, but a modern public policy gained a personified character [10]. The possibility of a politcal leader to affect social and economic processes, to define a vector of social transformations now depends considerably upon to what extent leader's legitimacy and support are the result of a rational choice of the population or the result of the specific organization of a political discourse [20, 30, 31].

A fundamental importance for today's Russia belongs to the system of mass political communication withing the limits of which the representation of political

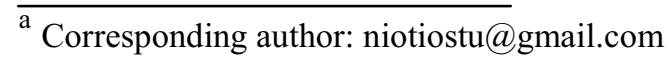

practice is carried out, including the representation of the image of a political leader.

\section{Investigation methods}

To solve the research problem the authors have used a discourse analysis method, the method of contentanalysis of 514 texts of the program «Time » of the first Russian TV-channel (December 20 - June 20, 2010) ; an inquiry method ( $\mathrm{N}=400$, quota sampling, 2014), a documentation qualitative analysis.

Historically, a discourse is a linguistic category and within the limits of a linguistic approach is undestood as a concrete result of communication, as a complex communicative event which takes place between a speaker, a listener and observer in the course of communication in a particular temporal and spatial aspect. (R.M Blakar, T.A. van Dijck, M.V. Jorgensen, U. Eko).

A discourse in a sociological theory is used most 
often for marking the empirical object of investigations, that is, communication practices connected with a certain agent or social practice, for example, a medical discourse, President's discourse, a discourse of violence and so on $[12,28]$.

The purpose of the discourse-analysis is revealing a deep sense in social communication, the definition of the influence of a social and other context upon it [16, 22].

\section{Political discourse}

\subsection{Foucault methodology}

The author's approach to the definition of a political discourse is based on the Foucault methodological reasons who interprets a discourse as a dynamic battlefield of different ideologies, concepts, scientific images of the world which contain certain ideas of a social world. These reasons are the following :

a) the discourse represents a structural organization of elements (communicative acts, information, discourse objects), establishing rules of their interaction, cosubordination, legitimation and so on ;

b) each discourse is determined by a set rules of «formulation of statements» and definition of a discourse ;

c) power is the central category of any discourse and its spreading is carried out by means of a specific discourse practice itself containing technologies and strategies of power establishment;

d) the purpose of a discourse is the formation of a certain pattern of the world.

The Foucault methodological approach allows carrying out the «inversion» of a discourse analysis from the definition of a social context influence upon a concrete act of communication to the investigation of the process of the designing of social reality within the limits of specific discourse practice.

The approach mentioned allows investigating a political discourse as a practice of the designing of a certain reality and specific agents, institutions and organizations - discourse objects. Policy being a power discourse («the purpose of a political discourse is power conquest and its retention »), is structured by power relations and forms specific centres of power attraction.

\subsection{Concept, subjects and characteristics of political discourse}

A political discourse is defined by the authors as a simulative dynamic model of a political area representing a hierarchical space of interacting and fighting sub-discourses differentiated by power relations and organized on the basis of norms, regulations and principles of the knowledge formation about policy.

The subjects of the political discourse are images of subjects of the political area (leaders, statesmen, political parties and so on) developed by mass media. Its hierarchical and spatial organization belongs to the most significant characteristics of a political discourse.
The hierarchical position of a definite group of subjects of a discourse is defined by the presence of the influence upon mass media resources at the disposal of political subjects, whose interests reflect discourse subjects and mechanisms of influence upon a political discourse. It is also defined by the response of the audience (population) in the form of political behavior (including electoral one).

The spatial organization supposes that subjects of the discourse, similar in the opinions and interests, unite creating definite sub-discourses seeking to the domination in the whole of the political discourse. A discourse creates a space where subjects, ideologies, political agents, practice and institutions, centers of power are formed, and power capital is distributed and articulated through specific symbols of power.

The main purpose of a political discourse is a possibility of discourse subjects to legitimate a certain picture of political reality, obtaining the right for statements, for the formation of discussion rules. Due to a political discourse, political subjects of information and knowledge carry out the broadcast about policy to population; thus the system of political communication is formed.

A political discourse within the limits of the political system is carried out by means of mass media; that is why actually a political discourse is a media discourse of policy. Mass media are not only the broadcast institution, but also that of interpretation and organization of political information, and the most significant channel of the response articulation of the discourse audience.

\section{Representation of political leader image in political discourse}

\subsection{Representation of political discourse}

A basic mechanism in the political discourse formation is a representation which the authors understand as a process of object presentation on the basis of its substitution by other object or its image. The representation of a political discourse is carried out by means of the formation of a simulative model of policy on the basis of political symbols which supposes the transition of political reality into the area of symbolic struggle and the substitution of a real political process for political simulators.

Public policy mediatization in the aggregate with other factors results in that in today's Russia public policy gains more and more virtual character moving away from a real political process. The mass media influence upon the formation of a political discourse and representation of a political leader image is caused by the following functions of mass media in the system of political communication:

First, mass media determine a publicity mode of a political discourse, in consequence of which it obtains a free dialogue character. 
Second, mass media are a basic institution of policy representation and political discourse formation.

Third, mass media are one of the most significant power resources, a channel for the formation of public opinion, and for the presentation of political information. Fourth, mass media are a means for the definition of political identity and fifth, carry out the selection of political information being, in such a way, as a tool for the selection and nomination of information significance defining an "agenda".

\subsection{Practice in image representation of V.V. Putin, the President of the Russian Federation, in political discourse}

A positive attitude towards a leader applies to the whole of the political system, which she/he represents being a referent of a political field and reflecting peculiarities of the national political mentality. The political decisions making, political processes arise as those depending and based on the political leader will, her/his personal properties that defines the level of a symbolic significance and degree of sacralization of a political leader. Basic peculiarities in the representation of a political leader image are the following:

a) The representation of the political leader image supposes the representation of the totality of personal, social, professional and other information about the leader.

b) The representation of the political leader image is directed to a definite purposeful audience as such could be a social, ethnic or professional group.

c) The representation of the political leader image is based on her/his articulation and objectivity round certain political symbols expressing cultural values and purposes, ideology, political concepts. The analysis of data obtained in the course of sociological investigations (questionnaire), allowed accenting the following images of V.V. Putin as a political leader: "people's president", "champion-intelligence officer", "yard kid", "manfather". For the representation of a political leader image symbolic codes are used. A symbolic code is a system of regulations and principles which supposes a certain interpretation of political symbols, statements of their power modality and organization of discourse area. A taxonomy code supposes that a political leader image is designated as connected with certain cultural standards, value orientations, stereotypes or ideology. The qualitative analysis of texts in TV news of the "First Channel" has shown that a central symbolic image for the Russian President is the image of a super-hero. "Army", "Navy", "Security Services", "Sports", "Northern Caucasia", "Ukraine", "Georgia", "Economic Crisis Control", "Social Sphere" - became referent topics for his super-hero-image. V. Soloviyov, the wellknown Russian journalist, discoursing on V.V. Putin, as a politician, brings to the forefront his body with the emphasis upon his masculinity: "The idea of that V.V. Putin can still have children does not cause any rejection: a young healthy man, goes in for sports, abstainer. For many peopled in Russia, particularly for women, V.V. Putin is a sex-symbol... He is the incarnation of the dream of majority of Russian women about what kind a man is to be. Thank God, that we succeeded in reaching a moment when the country is ruled by a healthy, clever and honest man" $[4,81]$.

A taxonomy code supposes also a definite organization of features and characteristics of a leader, his biography round the central image they must not contradict each other and must correspond to the central image. V.V. Putin, a former intelligence officer, goes actively in for sports giving preference to wrestling (a widely-known photo of him with torso naked), does from time to time deeds which do not fall into a general pattern of a leader-governor, but corresponding to heroic behavior (from the flight in a supersonic fighter to a personal participation in fire extinguishing).

V. Soloviyov, in his book "Putin. A guidebook for the non-indifferent" in the image of V.V. Putin, side by side with exceptional moral, emphasizes his exceptional normality, commonness. The image of V.V. Putin is an embodiment of generally recognized principles and values in the national consciousness - a believer, loving father, democrat, but not a liberal, regarding work without fanaticism, a hard politician, and at the same time, a very kind and honest man, a personality of the exceptional scale and, at the same time, he is like everybody. The code of ordinariness makes the most significant influence upon the representation of a political leader image. The political leader image must be articulated at the level of everyday logic of an individual, and become apparent in everyday skill, thereby manifesting own reality and naturalness, tangibility and realization establishing a connection with inter-subjective reality. According to V. Soloviyov, the Russian President appears an ordinary man and a citizen who is loved for his naturalness. As a rule, all President's responses coincide with that of ordinary people, that is why Putin is a "tuning fork" of normality. A code of centering establishes the totality of leader power over all symbols round which an image articulation occurs. A leader comes forward as a subject producing political symbols and establishing their meanings for a discourse reality authentic to an image. For the image of V.V. Putin a national identity is the most complicated. V. Soloviyov, enumerating archetypical constituents of V.V. Putin's image, defines in such a way an identity relator between a leader and national mentality, "Putin is completely arche-typical, as a birch, and, at the same time he is an incarnation of a solder coming out of fire. He is both modest and not great - not in the least Iliya Muromets, rather IvanTsarevich. Everything in him is something correct: a fellow from people, a fellow from our town - all this is about Putin" [4, 103].

It is naturally that the achievements and enemies of Putin are always of Cyclopean scales: he gave back to the Russians pride, put the Americans in their place, told them everything he thought; he won the Olympic Games $-2014$.

A significant characteristic of V.V. Putin's image is conservatism, presumption of traditions protection, historical past. Traditions ensure social stability, that is 
why a historical past protection, an accent of attention on succession come forward for the public system a symbolic proof of own stability, continuity of own existence. "Let us not forget - I returned the anthem of the Soviet Union as the anthem of the Russian Federation".

Codes of the exercise of power and personal participation

Sacral and super-heroic features become objective in the body of a leader, that is why, in the discourse a corporal rhetoric is extrapolated upon political communication. In such a situation a physical state of the leader is interpreted as a state of power itself. During Yeltsin's presidency any information starvation with respect to his person was taken as a consequence of his disease that, in its turn, applied to the idea about the whole of the political system, as physical fault of a leader was associated with the whole of a political system.

As an example of leader's power objectivism by means of leader's physical state may be exemplified in the following text of a news discourse of April 29, 2010, "Vladimir Putin shook a bear's pad and offered Arctic scavenging". At the same time it is necessary to emphasize that a bear is one of the arche-typical symbols of Russia, and also the symbol of the party "United Russia”.

An identity establishment between a healthy body and power vertical allows, first, creating a specific leader's power potential - physical health and force; second, physical health causes a specific character of political rhetoric allows a leader to articulate his power through a contact and control over physical reality. A power concentration in the political leader's image results in that his figure, his surrounding, his any action obtain a power modality begin to be considered as symbols of power.

V.V. Putin's image, as a leader-superhero, from the point of view of ours is connected with the peculiarities of Russian political culture for which a loyal character, political absinthism are typical, and within the limits of which a leader must be a power center establishing an authoritarian ruling style.

\section{Conclusions}

The application of a discourse analysis method allows considering a political discourse not only as a communicative political practice, but also as an information area creating knowledge of policy, images, symbols as political discourse.

The mechanism of a political discourse formation is a process of representation, which is carried out on the basis of a number of principles, including a principle of domination in a political discourse of a subdiscourse of political leaders and political subjects close to them ideologically and pragmatically. A political leader gains a status of a subject establishing moral, social values of society, to which a modern media discourse contributes to the considerable extent.
A closed state, rigid stratified structure, absence of free power competition result in the disfunctioning of the political sphere in today's Russia. Under such conditions a political discourse, as a model of policy ensuring a communication between subjects of a political area in population acts as a means of the recovery and simulation of a political process.

The involvement of population in a political discourse (observation "on that side" of a screen, public discussion and so on), as a mechanism of a participation substitution in policy acting in the discourse of political subjects (having no real political capital), simulates a real fight of political forces, where an interaction with an opposition consists in the elimination of opposition forces from a political discourse and so on.

\section{References}

1. M. Ayupov, Power, 12, 10-13 (2010)

2. P. Bourdie, Sociology of Policy (Moscow, SocioLogos, 1993)

3. V.R. Soloviyov, Putin. Guidebook for Nonindifferent (Moscow, EKSMO, 2008)

4. M. Foucault, Archeology of Knowledge (SaintPetersburg, 1996)

5. L. Fillips, M.V. Jorgensen, Discourse-Analysis. Theory and Method (Moscow, Humanitarian Center, 2008)

6. E.B. Shestopal, Polis, 3, 47-57 (2013)

7. Henry Bäck, Leadership and Community Involvement, 65-101 (2005)

8. Jean Blondel, and Jean-Louis Thiébault, eds. Political leadership, parties and citizens: the personalisation of leadership (Routledge, 2009)

9. Olivier Börraz, and Peter John, International Journal of Urban and Regional Research, 28.1, 107120 (2004)

10. Archie Brown, and Lilia Shevtsova, eds. Gorbachev, Yeltsin, and Putin: political leadership in Russia's transition (Carnegie Endowment, 2013)

11. Alistair Cole, François Mitterrand: A study in political leadership (Routledge, 2013)

12. Malcolm Coulthard, An introduction to discourse analysis (Routledge, 2014)

13. Jennifer Curtin, Parliamentary Affairs, 61.3, 490504 (2008)

14. Fernando Ferreira, and Joseph Gyourko, Journal of Public Economics, 112, 24-39 (2014)

15. Bjőrn Furuholt, and Wahid Fathul, Hawaii International Conference on System Sciences, Proceedings of the 41st Annual. IEEE (2008)

16. James Paul Gee, An introduction to discourse analysis: Theory and method (Routledge, 2014)

17. Mike Goldsmith, and Helge Larsen, International journal of urban and regional research, 28.1, 121133 (2004)

18. Cathy Gormley-Heenan, Palgrave Macmillan (2006)

19. Ludger Helms, The Political Quarterly, 76.3, 430438 (2005)

20. Siegfried Jäger, Methods of critical discourse analysis, 2, 32-63 (2001) 
21. Farida Jalalzai, and Mona Lena Krook, International Political Science Review, 31.1, 5-21 (2010)

22. Marianne W. Jorgensen, and Louise J. Phillips, Discourse analysis as theory and method (Sage, 2002)

23. Michael Laver, Michael Gallagher, and Peter Mair, Representative government in modern Europe (McGraw-Hill, 2011)

24. Scott O. Lilienfeld, et al. Journal of personality and social psychology, 103.3, 489 (2012)

25. Kevin Morrell, and Jean Hartley, Human Relations, 59.4, 483-504 (2006)

26. Sonja Opper, and Stefan Brehm, Networks versus performance: Political leadership promotion in China (Department of Economics, Lund University, 2007)

27. Dae-Sook Suh, ed. Political Leadership in Korea (University of Washington Press, 2014)

28. Stefan Titscher, and Bryan Jenner, Methods of text and discourse analysis: In search of meaning (Sage, 2000)

29. Mino Vianello, and Gwen Moore, eds. Gendering elites: economic and political leadership in 27 industrialised societies (Macmillan Press, 2000)

30. Ruth Wodak, and Michal Krzyzanowski, Qualitative discourse analysis in the Social Sciences (Palgrave Macmillan, 2008)

31. Linda A. Wood, and Rolf O. Kroger, Doing discourse analysis: Methods for studying action in talk and text (Sage Publications, 2000) 